\title{
Impacts of biogenic structures on benthic assemblages: microbes, meiofauna, macrofauna and related ecosystem functions
}

\author{
Claire Passarelli $^{1, *}{ }^{\text {, Frédéric Olivier }}{ }^{1,2}$, David M. Paterson ${ }^{3}$, Cédric Hubas ${ }^{1}$ \\ ${ }^{1}$ Muséum National d'Histoire Naturelle, UMR BOREA 7208 MNHN/CNRS/IRD/UPMC, 75231 Paris Cedex 5, France \\ ${ }^{2}$ ISMER / UQAR, CP3300 Rimouski, Quebec G5L 3A1, Canada \\ ${ }^{3}$ Sediment Ecology Research Group, Scottish Oceans Institute, University of St Andrews, St Andrews, KY16 8LB, UK
}

\begin{abstract}
Species that modify their surroundings are known as ecosystem engineers. For example, patches of polychaete tubes enhance soft-bottom intertidal habitat complexity, modifying water flow, promoting sediment accretion and affecting nutrient fluxes at the water-sediment interface. Understanding how such structures affect the benthic ecosystem's functioning requires the assessment of their influence on all benthic components and how the related ecosystem services may be modified. We performed an in situ experimental study, involving the use of artificial mimics of polychaete tubes, to investigate the purely physical impacts of the structures without the complexity of worm activity. Benthic chambers of different mimic densities were used, and their effect on the recolonisation of defaunated natural sandy sediments by microorganisms, meiofauna and macrofauna was monitored. We also measured air-sediment $\mathrm{CO}_{2}$ fluxes and sediment stability as they constitute crucial ecosystem services provided by benthic habitats. We showed that the biogenic structures stimulated the development of diatom biofilms (microphytobenthos) and their associated extracellular polymeric substances (EPS). Impacts of tubes on meiofaunal and macrofaunal assemblages were significant; in most cases, species and groups were more abundant in treatments with few or no tubes. In response to the tube density increase, the whole system tended towards heterotrophy and higher sediment stability, probably as a consequence of the development of the diatom biofilm. Biogenic structures are, therefore, of critical importance for soft-bottom intertidal communities in terms of both structure and function.
\end{abstract}

KEY WORDS: Biogenic structures $\cdot$ Polychaete tubes $\cdot$ Biofilm $\cdot$ Microphytobenthos $\cdot$ Meiofauna Macrofauna $\cdot$ Carbon flux $\cdot$ Sediment stability

\section{INTRODUCTION}

In soft-bottom intertidal areas, biogenic features are known to structure and modulate the habitat and have a major influence on the distribution of species and individuals (Zuhlke et al. 1998). Many benthic organisms alter water flow at the sediment surface and, therefore, alter the resuspension of sediment and the relative flux rates across the sediment-water boundary, which affects the availability of nutrients and oxygen (Nowell \& Jumars 1984, Friedrichs et al. 2009). By modifying both habitat and access to resources for other organisms, these species are often classified as ecosystem engineers (Jones et al. 1994). Examples of biogenic structures include polychaete tubes (Eckman et al. 1981), mollusc shells (Moulin et al. 2007) and coiled faecal casts (Friedrichs et al. 2009). Organisms building these structures may have 
specific behaviours that affect community metabolism, such as fluid pumping by Lanice conchilega (Forster \& Graf 1995) or antibiotic production by Notomastus lobatus (Steward et al. 1996), but one of their common features is the production of roughness elements (Nowell \& Jumars 1984), which modify boundary hydrodynamics. However, to fully understand ecosystem engineering activity, it is desirable to be able to separate the effect of the structure from the effect of the structure plus the ecosystem engineer itself.

The influence of biogenic structures on sediment has been extensively studied through flume experiments (Eckman et al. 1981, Nowell \& Jumars 1984, Luckenbach 1986, Friedrichs et al. 2000, Friedrichs et al. 2009). These experiments have highlighted distinct types of hydro-sedimentary patterns depending on the relative flow rates and densities and shapes of the structures involved. These interactions may promote or hinder the activity of different species depending on their preference for stable or unstable sediment (Woodin \& Jackson 1979, Volkenborn et al. 2009). Destabilisation of the substratum was mostly observed at moderate to high flow, with low densities of roughness elements (interactive flow), while stabilisation of the sediment occurred at higher densities, which induced 'skimming flow' where the effective hydrodynamic boundary is displaced above the element field (Nowell \& Jumars 1984). This 'skimming flow' regime promotes both deposition of particles and the reduction of erosive stress at the surface of the bed.

The engineering effect of biogenic structures on macrofaunal assemblages has long been demonstrated in laboratory flumes and in the field (e. g. Woodin 1978, Luckenbach 1986, Zuhlke 2001, Callaway 2006). However, data are scarce on other groups of organisms, such as micro-organisms (microphytobenthos and bacteria) and meiofauna. These smaller organisms are likely to respond more quickly to changes in the hydro-sedimentary dynamics promoted by different biogenic structures (Eckman 1983, 1985) since they generally display relatively rapid turnover rates. Studying these organisms may be crucial to fully understand the engineering effects of biogenic structures, and how they alter ecosystem processes, such as carbon fluxes. In some systems, bacteria are known to be the main contributors to benthic respiration (Schwinghamer et al. 1986, Azam et al. 1994, Hubas et al. 2007). Furthermore, the observed changes in ecosystem dynamics associated with biogenic structures might not be directly explained by hydrody- namics. For example, there may be an indirect effect of the hydro-sedimentary conditions favouring the development of microbial biofilms and associated extracellular polymeric substances (EPS; Eckman et al. 1981). Indeed, the biofilm matrix has a stabilising effect on the sediment, but its efficiency depends on both composition and concentration of the EPS (van Duyl et al. 2000, de Brouwer et al. 2005).

The present work focuses on the effect of biogenic structures on benthic communities, including microorganisms, meiofauna and macrofauna, and specific related ecosystem functions. Specifically, we monitored the effects of artificial polychaete tubes on the re-colonisation of sediment by natural benthic assemblages in a sandy intertidal area. Carbon flux and sediment stability were also chosen as measures of related ecosystem functions. We tested the hypotheses that (1) biogenic structures stimulate biofilm development; (2) this intensification of the biofilm development increases the abundance of meiofaunal assemblages; (3) macrofaunal abundance and diversity increase with tube density and (4) there are cascading effects on carbon fluxes and sediment stability due to such changes in the benthic assemblages. An in situ experiment was conducted by establishing benthic chambers with varying biogenic effects (no tubes, low tube density and high tube density) in the intertidal area and monitoring the response over 2 mo.

\section{MATERIALS AND METHODS}

\section{Study site}

Experiments were carried out during spring 2010 in the Chausey archipelago (France) within the Normand-Breton Gulf (English Channel), which is characterized by a megatidal regime (tidal range up to $14 \mathrm{~m}$ ). The Chausey archipelago includes 1500 ha of soft sediment tidal flats (Toupoint et al. 2008).

\section{Experimental design}

Twelve cylindrical benthic chambers of $300 \mathrm{~mm}$ inner diameter and $60 \mathrm{~mm}$ depth were used (Fig. 1). Solid PVC cylindrical rods were fixed to the bottom of each benthic chamber, simulating tubes of large polychaete species, such as Lanice conchilega or Melinna cristata (5 $\mathrm{mm}$ diameter, $95 \mathrm{~mm}$ length). Three treatments were used (4 replicate chambers 

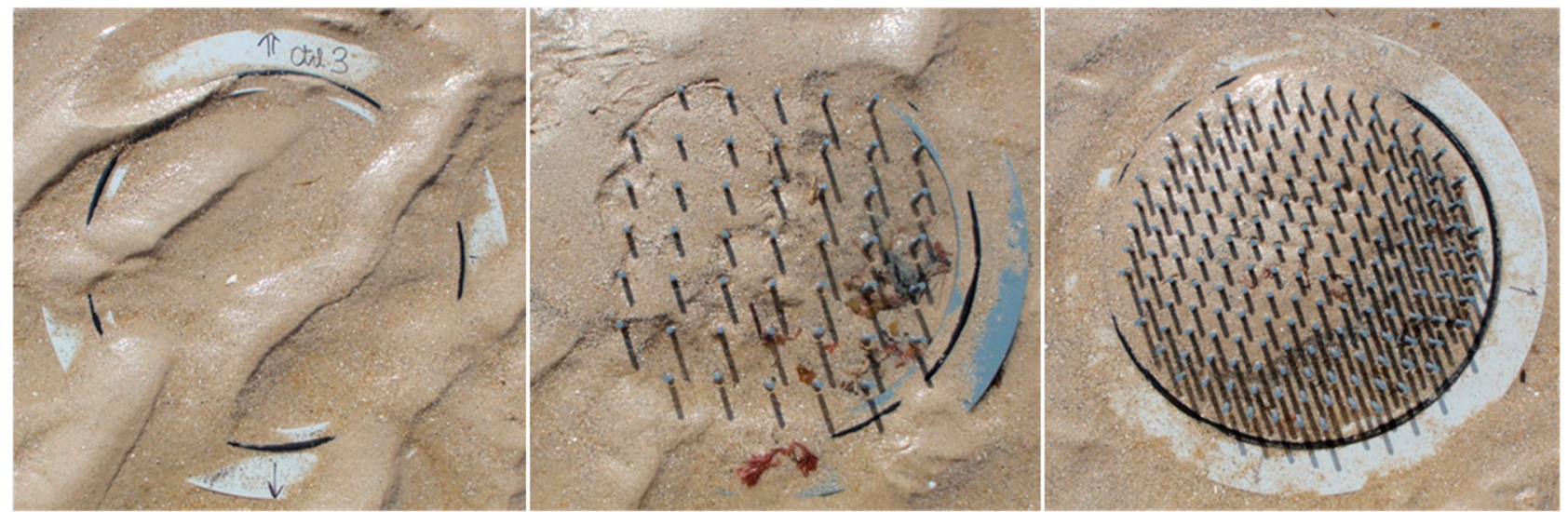

Fig. 1. Pictures of the benthic chambers $2 \mathrm{wk}$ after their installation on tidal flats. From left to right: no tubes (Ctrl), low tube density (LD) and high tube density (HD) treatments

per treatment); a control treatment (Ctrl), without tubes; then 2 test treatments with varying densities of evenly spaced tubes: a low density (LD) treatment with 45 tubes per chamber (1.3\% of surface covered, equivalent of 637 tubes $\mathrm{m}^{-2}$ ) and a high density treatment (HD) with 177 tubes per chamber (4.9\% of surface covered, 2505 tubes $\mathrm{m}^{-2}$ ). The LD treatment was chosen according to the literature to be potentially destabilising (to initiate interactive flow; Friedrichs et al. 2000), whereas the HD treatment was chosen for its stabilising effect (to initiate skimming flow; Friedrichs et al. 2000). These densities were both within the range of natural densities for polychaete tubes (up to 5000 ind. $\mathrm{m}^{-2}$; e.g. Friedrichs et al. 2000 for Melinna cristata).

Before establishing the chambers in the field, they were filled with defaunated (frozen and thawed) sand from the study site (medium sand, median grain size between 260 and $300 \mu \mathrm{m}$ ). They were then placed into the intertidal area on March 2, with a $2 \mathrm{~m}$ gap between chambers. The chambers were embedded into the sediment so that only the tops $(35 \mathrm{~mm})$ of artificial tubes protruded from the substratum. Sampling was carried out every $2 \mathrm{wk}$ from the beginning of the experiment to April 27. This period was chosen to encompass the increase in biological activity after winter. Sampling locations within the chambers were randomly chosen for each sampling time, so that samples were never taken from the same location throughout the course of the experiment. Observation of the plots showed that within $24 \mathrm{~h}$ of the measurements, any cavities created by sampling were infilled by natural sediment, and no trace of the sampling was apparent (pers. obs.).

Samples from April 14 (Day 44) were excluded from the analysis due to freezer malfunction.

\section{Sampling and measurements}

Organic matter (OM) content. One sediment sample was taken from each benthic chamber at every sampling time $(2 \mathrm{~cm}$ inner diameter cut off syringe, $2 \mathrm{~cm}$ depth). Samples were frozen until analysis and OM content was determined by loss-on-ignition of dry mass from the sediment (Higgins \& Thiel 1988): samples were dried at $60^{\circ} \mathrm{C}$ for $24 \mathrm{~h}$, weighed, and then burned at $550^{\circ} \mathrm{C}$ for $4 \mathrm{~h}$, and weighed again.

Chlorophylls. Three samples were taken from every benthic chamber at every sampling time $(2 \mathrm{~cm}$ inner diameter cut off syringe, $2 \mathrm{~mm}$ depth). This sampling depth was chosen to target photosynthetically active biomass only (Black \& Paterson 1996, Paterson et al. 1998). Samples were frozen until analysis. Then, $5 \mathrm{ml} 90 \%$ acetone was added to each sample for pigment extraction (16 h in darkness). Concentrations of chlorophylls $a, b$ and $c$ were determined by spectrophotometry (Spectronic Genesys 2 spectrophotometer, Milton Roy; Jeffrey et al. 1997).

Bacterial cell number. Three samples were taken from each benthic chamber at every sampling time $(2 \mathrm{~cm}$ inner diameter cut off syringe, $2 \mathrm{~mm}$ depth). Samples were frozen until analysis, and then fixed with formalin ( $1 \%$ final concentration). Samples were stained with Syto13 (Molecular Probes, $1.2 \mathrm{umol} \mathrm{l}^{-1}$ final concentration), left for $15 \mathrm{~min}$ in the dark and measured by flow cytometry (Becton Dickinson FACSort ${ }^{\mathrm{TM}}$ with a laser emitting at $488 \mathrm{~nm}$ ). The flow rate was fixed to $27 \mu \mathrm{mol} \mathrm{min}{ }^{-1}$ and data were recorded until 10000 events were acquired or $1 \mathrm{~min}$ had passed. Bacteria were detected by plotting the side light scatter (SSC) versus green fluorescence (FL1). An internal standard was added to some samples (PeakFlow ${ }^{\mathrm{TM}}$ reference beads $2.5 \mu \mathrm{m}$, Molecular 
Probes). The acquisition was limited to a gate encompassing the bacterial population.

EPS. Three samples were taken from each benthic chamber at every sampling date $(1.5 \mathrm{~cm}$ inner diameter cut off syringe, $2 \mathrm{~mm}$ depth). Samples were frozen until analysis. Every sample had $2 \mathrm{ml}$ distilled water added to it and was continuously rotated for $90 \mathrm{~min}$ at room temperature (Horizontal mixer, RM5-30V, Ingenieurbüro CAT), allowing the extraction of colloidal EPS. The supernatant was then analysed by colorimetry for carbohydrates and proteins. Carbohydrates and proteins were analysed according to the Dubois (Taylor \& Paterson 1998) and modified Lowry (Frolund et al. 1996) methods, respectively. See Lubarsky et al. (2010) for more detailed procedures.

Meiofauna colonisation. Three samples were taken from every benthic chamber at every sampling time $(2 \mathrm{~cm}$ inner diameter cut off syringe, $2 \mathrm{~cm}$ depth). Samples were immediately fixed in 50\% ethanol and stored until analysis. Meiofauna was extracted from the sediment using colloidal silica soil Ludox ${ }^{\circledR}$ HS 40 following the procedure from Burgess (2001). Extraction efficiency of this method has been estimated as better than $95 \%$, except for foraminifera $(87 \%)$ which can remain in the pellet after this extraction protocol. Animals extracted were identified and counted. Since foraminifera were very abundant, $0.75 \mathrm{~g}$ of the pellet was also analysed to ensure inclusive analysis of their population; the pellet was weighed and the total number of foraminifera was deduced.

Macrofauna colonisation. The sediment in every chamber was sieved through a $500 \mu \mathrm{m}$ sieve at the end of the experiment and immediately fixed with $4 \%$ formalin in seawater. All macrofaunal organisms were identified to species level.

Carbon fluxes. $\mathrm{CO}_{2}$ fluxes at the air-sediment interface were measured in situ with a closed-chamber method developed by Migné et al. (2002). The measurements were made with a transparent or opaque dome that fit onto the benthic chamber and was made airtight. Air flow was set in motion by a pump and channelled through a dessicator and was then analysed with a $\mathrm{CO}_{2}$ infrared gas analyser (LiCor Li 800). Changes in air $\mathrm{CO}_{2}$ partial pressure were measured in ppm. Data were recorded every $30 \mathrm{~s}$ and $\mathrm{CO}_{2}$ fluxes were calculated from the recorded data using the slope of $\mathrm{CO}_{2}$ concentration against time. Measurements were made at ambient light (transparent dome) in order to assess net benthic primary production, and then in darkness (opaque dome) to assess benthic respiration. Benthic gross primary production was deduced from these fluxes. Given the time necessary for each measurement (more than $90 \mathrm{~min}$ ), only one measurement per treatment per sampling date was performed.

Sediment stability. Sediment stability was assessed through the proxy of surface adhesion. The ability of the surface to retain particles was measured by Magnetic Particle Induction (MagPI), a device recently developed by Larson et al. (2009). Briefly, a given amount of ferrous and stained particles were spread onto the sediment surface. Then, the magnetic force needed to detach the particles from the substratum was measured, using a variable electromagnet set at a specific distance from the test surface. The current supplied to the magnet controlled the strength of the magnetic field and the force required to remove the ferrous particles was recorded (Larson et al. 2009).

Three samples were taken from each benthic chamber at every sampling time $(2 \mathrm{~cm}$ inner diameter cut off syringe), without disturbing the sediment surface (no contact between piston and sediment). The cores were maintained vertically, transferred to laboratory and analysed within hours. Ferrous particles (diameter $>425 \mu \mathrm{m}$ ) were spread onto the sediment surface in a single layer. The electromagnet was set $3 \mathrm{~mm}$ away from sediment surface and connected to a variable voltage power supply (HY3005 DC Power Supply, Mastech). Voltage was increased from $0 \mathrm{~V}$ by increments of $0.1 \mathrm{~V}$ until all particles detached from sediment. This final voltage was recorded and the magnetic force associated was determined using a calibration curve previously established with a gaussmeter (410-HCAT, LakeShore). This magnetic flux (mT) was used as a measure of surface adhesive capacity. This measurement has been correlated with Cohesive Strength Meter (CSM) measurements (Lubarsky et al. 2010).

\section{Statistics}

Since biofilm related data violated assumptions of homogeneity of variance and normality, even after transformation, we used non-parametric statistics under the R statistical framework. For each sampling time, differences between treatments were assessed by Kruskal-Wallis tests (KW; the mean of the 3 measurements was used for each chamber). When the KW test was significant, we performed non parametric Student-Newman-Keuls (SNK) tests to assess differences between the groups. Differences between sampling times were assessed by Friedman tests (consid- 
ering data from each chamber as paired data; the mean of the 3 measurements was used for each chamber). Correlation between biofilm variables was assessed with Spearman's correlation coefficient (one measure per chamber per sampling time was used).

To analyse the differences between meiofaunal and macrofaunal assemblages, similarity matrix were constructed using Bray-Curtis distances on standardised data (Primer 5 software). Non-metric multidimensional scaling (n-MDS) analyses were performed using these matrixes (200 iterations). An analysis of similarity (ANOSIM) was then used to assess the differences between assemblages (5000 iterations), at different times for the meiofauna and at the end of the experiment for the macrofauna.

As every carbon flux measurement was highly time consuming, only one measurement per sampling time per treatment was done. In order to test differences between treatments, carbon flux measurements of each treatment were pooled from every sampling date after the first day of the experiment. The ratio between gross primary production and respiration rates was calculated and differences between treatments were then analysed with the KW test.

\section{RESULTS}

\section{Microbial assemblages}

OM content significantly increased between the beginning and the end of the experiment in every treatment (data not shown; Friedman test, $\mathrm{p}<0.05$ ).
OM content was highest in HD treatment and lowest in control chambers, and differed significantly between treatments after $2 \mathrm{wk}$ and 2 mo of experiment (KW test, $\mathrm{p}<0.05$; Table 1 ).

Chlorophyll a (chl a) content increased during the experiment (Friedman test, $\mathrm{p}<0.01$ ) and was always minimal in control chambers (KW test, $\mathrm{p}<0.05$ ). It was higher in HD chambers, intermediate in LD chambers and lower in control chambers, but the difference between $\mathrm{HD}$ and LD chl a contents was no longer significant at the end of the experiment (Fig. 2a, Table 1). Chl $b$ contents varied significantly during the experiment but with no visible trend, while the dynamics of chl $c$ content was similar to those of chl a content (data not shown; Table 1).

Bacterial densities were highly variable during the sampling period, from $9 \times 10^{7}$ to $1.5 \times 10^{10}$ bacteria $\mathrm{cm}^{-3}$ (Fig. 2b), with no significant differences between treatments (KW test, $\mathrm{p}>0.05$; Table 1 ).

Carbohydrate concentrations increased significantly in each treatment during the sampling period (Fig. 3a; Friedman test, p < 0.05), whereas protein concentrations increased in LD chambers only (Fig. 3b, Friedman test, $\mathrm{p}<0.05$ ). If the first measurement, which corresponds to defaunated sands, is excluded, EPS concentrations were generally higher in LD and HD treatments. The differences between treatments became significant after 1 mo for protein and 2 mo for carbohydrates (Table 1). Surprisingly, EPS concentrations were highest for the LD treatment at the end of the experiment, whereas previously they tended to be highest for the HD treatment.

Table 1. Results of statistical tests on biofilm variables. The first line for each variable displays the result of a global test (Kruskal-Wallis test; ns: not significant; ${ }^{*} \mathrm{p}<0.05 ;{ }^{* *} \mathrm{p}<0.01$ ). The second line displays the results of post-hoc tests (non parametric Student-Newman-Keuls tests; different if $\mathrm{p}<0.05$ where these tests are appropriate and show significant differences). OM: organic matter. Ctrl: no tubes. LD: low tube density. HD: high tube density

\begin{tabular}{|c|c|c|c|c|}
\hline & & Day 14 & Day 27 & Day 56 \\
\hline $\mathrm{OM}$ & Global test & * & ns & * \\
\hline Chl a & $\begin{array}{l}\text { Global test } \\
\text { Pairwise comparison }\end{array}$ & ns & $\mathrm{Ctrl}<\mathrm{LD}<\mathrm{HD}$ & $\left.\mathrm{Ctrl}<{ }_{(\mathrm{LD} H D}\right)$ \\
\hline Chl $b$ & $\begin{array}{l}\text { Global test } \\
\text { Pairwise comparison }\end{array}$ & ns & $\mathrm{HD}<\mathrm{Ctrl}<\mathrm{LD}$ & $\stackrel{*}{(\mathrm{LD} \mathrm{HD})}<\mathrm{Ctrl}$ \\
\hline $\mathrm{Chl} C$ & $\begin{array}{l}\text { Global test } \\
\text { Pairwise comparison }\end{array}$ & $\mathrm{ns}$ & $\mathrm{Ctrl}<{ }^{*}(\mathrm{LD} H D)$ & $\mathrm{Ctrl}<{ }^{*}$ (LD HD) \\
\hline Bacterial abundances & Global test & ns & ns & ns \\
\hline Carbohydrates & $\begin{array}{l}\text { Global test } \\
\text { Pairwise comparison }\end{array}$ & $\mathrm{ns}$ & $\mathrm{ns}$ & $\stackrel{*}{*} \operatorname{Ctrl}<\mathrm{HD}<\mathrm{LD}$ \\
\hline Proteins & $\begin{array}{l}\text { Global test } \\
\text { Pairwise comparison }\end{array}$ & ns & $\mathrm{Ctrl}<\mathrm{LD}^{* *}<\mathrm{HD}$ & $\mathrm{Ctrl}<\mathrm{HD}^{* *}<\mathrm{LD}$ \\
\hline
\end{tabular}



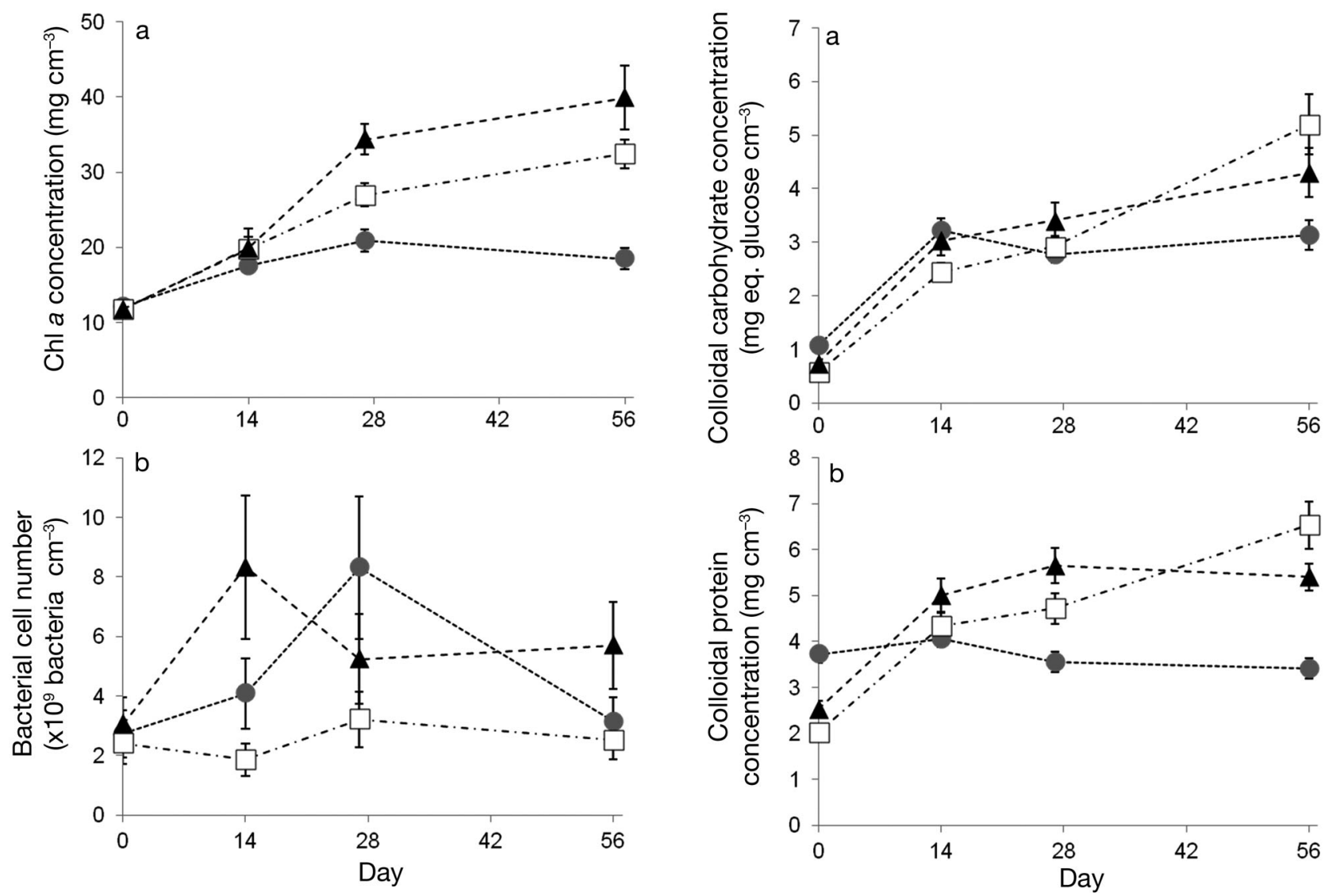

Fig. 2. Mean values of (a) chlorophyll ( $\mathrm{chl}$ a) a concentrations and (b) bacterial cell number over the course of the experiment. The different treatments were no tubes ( $\mathrm{Ctrl}, \bigcirc)$, low tube density $(\mathrm{LD}, \square)$ and high tube density $(\mathrm{HD}, \mathbf{\Delta})$. Points are means $\pm \mathrm{SE}$

Fig. 3. Mean values of EPS concentrations over the course of the experiment: (a) carbohydrates and (b) proteins. The different treatments were no tubes $(\mathrm{Ctrl}, 0)$, low tube density $(\mathrm{LD}, \square)$ and high tube density $(\mathrm{HD}, \boldsymbol{\Delta})$. Points are means $\pm \mathrm{SE}$

\section{Meiofaunal assemblages}

Total abundance of meiofaunal organisms increased through time in every treatment (Fig. 4; Friedman tests, $\mathrm{p}<0.01$ ), and was significantly different between treatments at every sampling time (KW tests, $\mathrm{p}<0.001$ ). Total abundance of meiofauna was significantly higher in HD chambers compared to the other treatments. Foraminifera were the most abundant meiofaunal group found in the benthic chambers. Their densities ranged from $4 \times 10^{5}$ ind. $\mathrm{m}^{-2}$ at the beginning of the experiment to $1 \times 10^{7}$ ind. $\mathrm{m}^{-2}$ in HD chambers at the end. Nematodes, the second most abundant group, exhibited densities ranging from $3 \times 10^{4}$ to $3 \times 10^{5}$ ind. $\mathrm{m}^{-2}$. We also found (in order of decreasing abundance) polychaetes, copepods, ciliates, halacarids, ostracods, tardigrades, oligochaetes and cumaceans (see Table A1 in Appendix 1 for details on meiofaunal abundances).

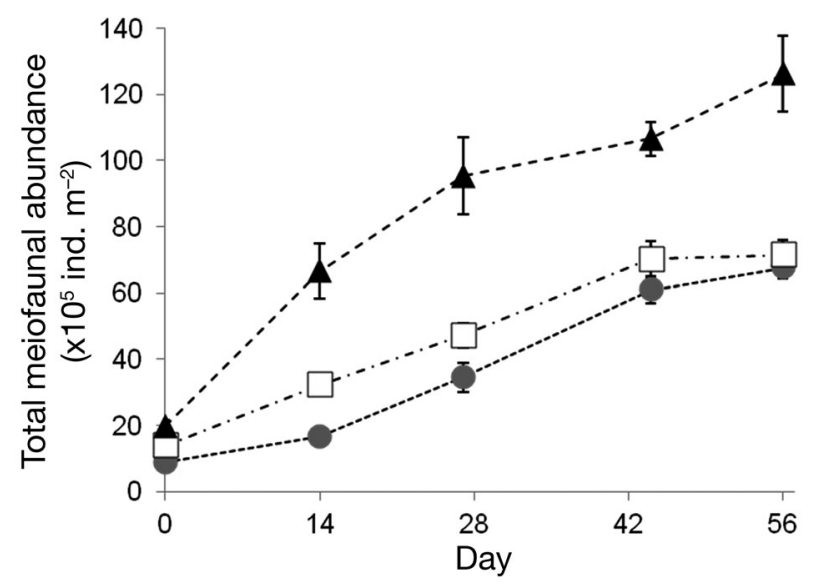

Fig. 4. Total meiofaunal abundances over the course of the experiment. The different treatments were no tubes (Ctrl, ๑), low tube density (LD, $\square$ ) and high tube density (HD, $\mathbf{\Delta}$ ). Points are means $\pm \mathrm{SE}$ 
Foraminifera were more abundant in HD chambers than in the other chambers, and the differences were significant throughout the duration of the experimentation (KW tests, $\mathrm{p}<0.01$ ); densities increased significantly during the sampling period (Friedman tests, $p<0.01$ ). Most other species showed an opposite pattern, with higher abundances in the control treatment at the end of the experiment (KW tests, $\mathrm{p}<$ 0.05 except for nematodes, cumaceans and oligochaetes). Meiofaunal assemblages differed between treatments after $2 \mathrm{wk}$, and the assemblages found at the end of the experiment were specific to each treatment (Fig. 5, Table 2).

\section{Macrofaunal assemblages}

Twenty-one species of macrofauna were identified, all of them at very low densities (max. density of 127 ind. $\mathrm{m}^{-2}$, for Bathyporeia guilliamsoniana). The most abundant group was amphipods, mainly represented by B. guilliamsoniana, B. sarsi and Gammarus oceanicus (see Table A2 in Appendix 1 for details on macrofaunal abundances). Polychaetes were less abundant and were dominated by Nephtys cirrosa and Spio martinensis. Macrofaunal assemblages differed significantly between treatments at the end of the experiment (Table 2). Only 7 species were found in HD chambers, compared to 13 in control treatments and 16 in LD chambers. In particular, B. guilliamsoniana was restricted to the control treatments, and the abundances of $B$. sarsi also tended to be higher in the control than in tube treatments (KW test, $\mathrm{p}>0.05)$. In contrast, $N$. cirrosa and Mediomastus fragilis were more abundant in chambers with tubes as compared to control chambers (significant for $N$. cirrosa, KW test, p < 0.01). Simpson's diversity indexes tend to be highest in LD chambers, and lowest in HD chambers (KW test, $\mathrm{p}>0.05$ ).

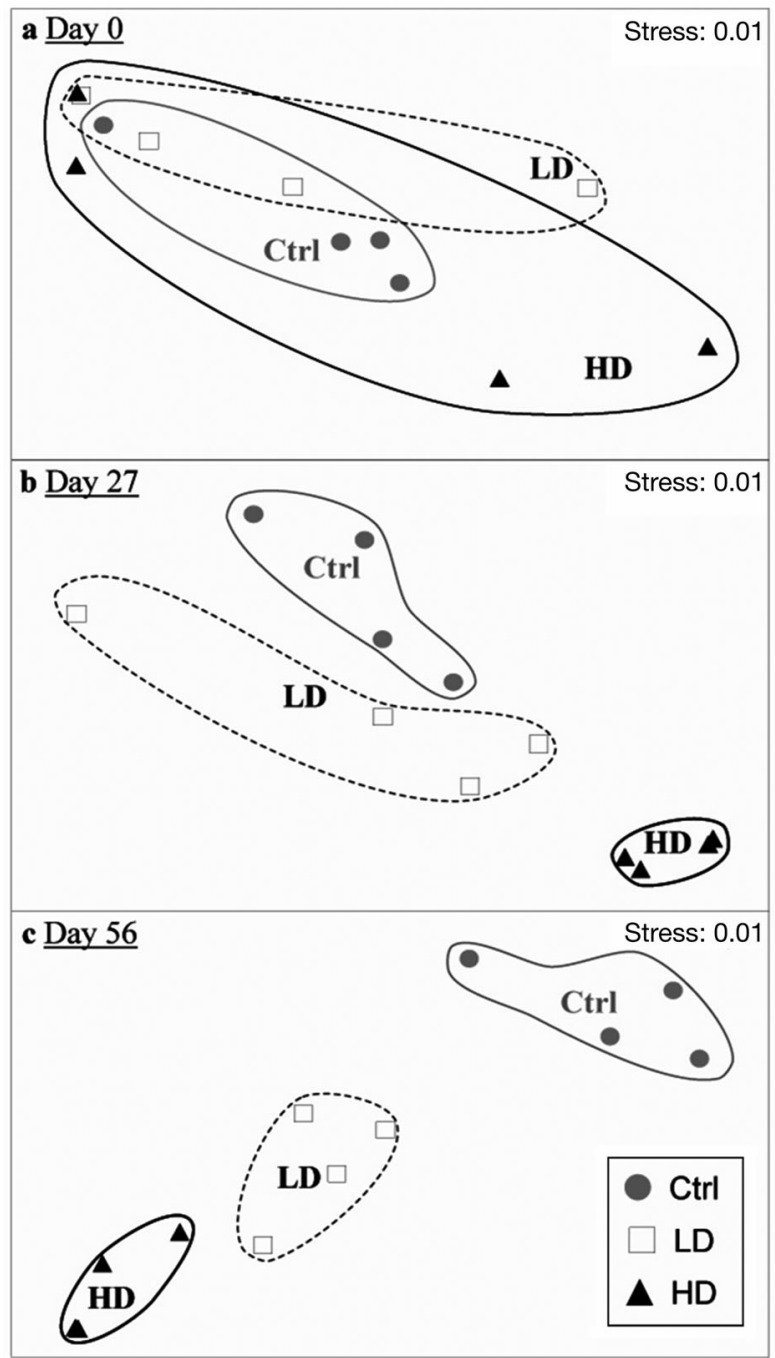

Fig. 5. n-MDS on meiofaunal assemblages over the course of the experiment: (a) at the beginning of the experiment, (b) after $1 \mathrm{mo}$, and (c) after 2 mo. The different treatments were: no tubes $(\mathrm{Ctrl}, 0)$, low tube density $(\mathrm{LD}, \square)$, and high tube density $(\mathrm{HD}, \mathbf{\Delta})$. The low values of stress indicate that the representation is reliable: distances between symbols correlate well with dissimilarities between chambers

\section{Ecosystem functions}

Gross primary production and respiration rates tended to increase from 2 wk to 2 mo after the beginning of the experiment, and they were higher in treatments with tubes compared to control chambers (data not shown). Net primary production rate followed the same pattern and, by the end of the experiment, was maximal in HD chambers. Gross primary production/
Table 2. Results of ANOSIMs on meiofaunal and macrofaunal assemblages at different sampling dates. Global R, global p-value (bold if significant), and results of pairwise tests are shown (different if $\mathrm{p}<0.05$ ). Ctrl: no tubes. LD: low tube density. HD: high tube density

\begin{tabular}{|lrrrc|}
\hline Group & $\begin{array}{c}\text { Time } \\
(\mathrm{d})\end{array}$ & Global R & $\begin{array}{c}\text { Global } \\
\text { p-value }\end{array}$ & $\begin{array}{c}\text { Significantly } \\
\text { different groups }\end{array}$ \\
\hline Meiofauna & 0 & -0.058 & 0.575 & No \\
& 14 & 0.769 & $<\mathbf{0 . 0 0 1}$ & Ctrl $\neq$ LD $\neq$ HD \\
& 27 & 0.655 & $\mathbf{0 . 0 0 4}$ & (Ctrl LD) $\neq$ HD \\
& 44 & 0.637 & $\mathbf{0 . 0 0 1}$ & (Ctrl LD) $\neq$ HD \\
Macrofauna & 56 & 0.926 & $\mathbf{0 . 0 0 2}$ & Ctrl $\neq$ LD $\neq$ HD \\
& 56 & 0.664 & $\mathbf{0 . 0 0 2}$ & Ctrl $\neq$ (LD HD) \\
\hline
\end{tabular}




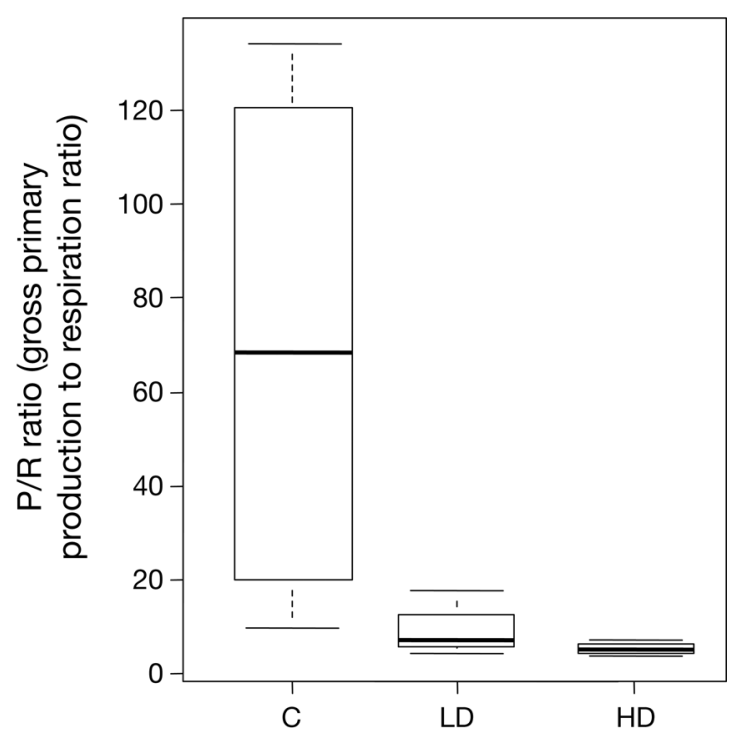

Fig. 6. Gross primary production to respiration ratio (P/R ratio). Data pooled from every sampling time, except the first day of experiment, were used. The different treatments were no tubes (Ctrl), low tube density (LD) and high tube density (HD). Box limits represent lower (Q1) and upper quartiles (Q3), midline represents sample median (Q2) and whiskers represent the smallest and largest observations.

No outliers were detected

respiration ratio (P/R ratio), using all measurements, was always higher than 1 and significantly lower for chambers with tubes compared to control chambers (Fig. 6 ; KW test, $\mathrm{p}<0.05$ ).

MagPI measurements showed differences in sediment adhesion between dates and treatments (Fig. 7). Sediment adhesion increased during the sampling period (Friedman test, $\mathrm{p}<0.01$ ). HD sediment adhesion was higher compared to LD or control treatments from $2 \mathrm{wk}$ to the end of the experiment (KW tests, $\mathrm{p}<0.05$ at every sampling time). Correlations between biofilm variables and sediment stability were tested by pooling data from all the sampling

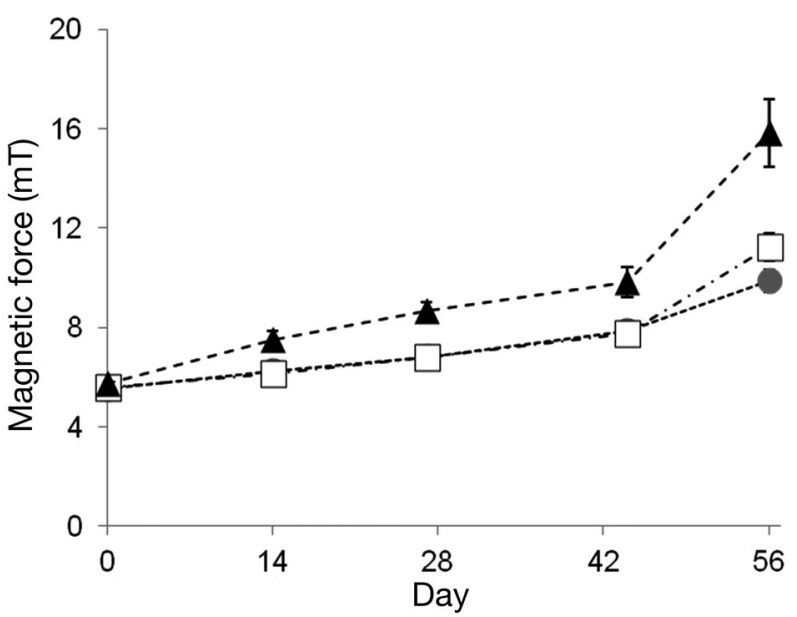

Fig. 7. Mean values of MagPI measurements over the course of the experiment. The different treatments were no tubes $(\mathrm{Ctrl}, \odot)$, low tube density (LD, $\square$ ) and high tube density

$(\mathrm{HD}, \boldsymbol{\Delta})$. Points are means $\pm \mathrm{SE}$

dates. Stability, chl a and $c$ contents, EPS concentration and $\mathrm{OM}$ content were significantly positively correlated (Table 3 ). Chl $b$ content was negatively correlated with most of these variables, while bacterial cell numbers appear to vary independently from other variables.

\section{DISCUSSION}

Organisms that produce biogenic structures can have 2 types of engineering effects: one through the structure itself, which provides habitat complexity and modifies the local hydrodynamics; and the second - more indirect - through the biological activities of the organisms (feeding, crawling or pistonpumping behaviours) or remineralisation processes. However, studies in flumes and in the field have often considered that the total influence of these

Table 3. Spearman's correlation coefficients and results of correlation tests between variables. The lower left part of the table shows Spearman's correlation coefficient between the 2 variables of interest (bold if significant: $p<0.05$ ). The upper right part shows the results of the correlation tests (ns: not significant; ${ }^{*} \mathrm{p}<0.05 ;{ }^{* *} \mathrm{p}<0.01 ;{ }^{* * *} \mathrm{p}<0.001$ ). OM: organic matter

\begin{tabular}{|c|c|c|c|c|c|c|c|c|}
\hline & MagPI & Carbohydrates & Proteins & Chl a & Chl $b$ & Chl $C$ & Bacteria & $\mathrm{OM}$ \\
\hline MagPI & & $* * *$ & $* * *$ & $* * *$ & $* * *$ & $* * *$ & ns & $* * *$ \\
\hline Carbohydrates & 0.80 & & $* * *$ & $* * *$ & $* * *$ & $* * *$ & ns & $* * *$ \\
\hline Proteins & 0.62 & 0.80 & & $* * *$ & * & ${ }^{* * *}$ & ns & $* * *$ \\
\hline Chl a & 0.76 & 0.72 & 0.74 & & $* *$ & $* * *$ & ns & $* * *$ \\
\hline Chl $b$ & -0.60 & -0.50 & -0.31 & -0.45 & & ns & ns & ns \\
\hline Chl $C$ & 0.66 & 0.69 & 0.76 & 0.93 & -0.22 & & ns & $* * *$ \\
\hline Bacteria & 0.16 & 0.20 & 0.11 & 0.08 & -0.01 & 0.04 & & ns \\
\hline $\mathrm{OM}$ & 0.66 & 0.66 & 0.67 & 0.67 & -0.21 & 0.67 & 0.18 & \\
\hline
\end{tabular}


organisms can be assigned to the effect of the structure alone (Thistle et al. 1984, Callaway 2003). Our results have demonstrated for the first time that, in nature, these structures have a wide range of effects on benthic assemblages, including microorganisms, meiofauna and macrofauna, and related ecosystem processes.

\section{Effects of biogenic structures on biofilms}

After 2 mo of incubation, sediments at the bottom of the artificial structures were enriched with organic matter and both chl $a$ and $c$, when compared to the control treatment. One explanation could be that the tubes themselves were colonised by microphytobenthic species, which enriched the sediment below after cells had been detached from the tubes. The alteration of the near-bed flow dynamics by artificial tubes may also explain the results. First, the presence of biogenic structures can entrain water flow and associated particles and nutrients towards sediment surface (Friedrichs et al. 2009), potentially stimulating microphytobenthos development. Moreover, under skimming flow conditions, the surface shear stress can be reduced by up to $75 \%$ (Friedrichs et al. 2000, Friedrichs \& Graf 2009), decreasing, therefore, the microphytobenthos resuspension, and allowing the settlement of fine particles and the enrichment of the superficial sediment. Due to bacterial remineralisation, such enrichment is likely to increase nutrient availability and, thus, to promote the growth of microphytobenthos.

In contrast, bacterial abundances were never affected by the presence of tubes, but the high variability observed could be explained by both natural patchiness and temporal variability of bacterial populations (Azam et al. 1994). Some studies have demonstrated that the sediment microphytobenthic enrichment stimulates either the bacterial production (van Duyl et al. 2000) or rapid changes in the structure of bacterial assemblages (Schäfer et al. 2002, Boivin et al. 2007, Lubarsky et al. 2010). Due to our sampling design, we cannot exclude the possibility that the influence of tubes on bacterial abundances might operate on a shorter time scale than the ones we examined (Eckman 1985).

The biofilm matrix, primarily composed of EPS, is an important component of the system. In this study, the proliferation of microphytobenthos was associated with higher EPS secretion, which was apparent as soon as tubes were present. EPS concentrations, for both colloidal carbohydrates and proteins, were correlated positively with chl $a$ and $c$, and negatively with chl $b$. This suggests an important contribution of diatoms to EPS secretion, as diatoms contain chl a and $c$, but not chl $b$ (Barranguet et al. 1997). Bacterial abundances were not correlated to EPS concentrations, although bacteria are well-known to contribute to EPS production in marine coastal biofilms (Decho 1990). The present study thus suggests that biogenic structures did not only promote microphytobenthos proliferation, but also biofilm development in terms of EPS content.

\section{Effects of biogenic structures on meiofauna and macrofauna}

At high tube densities, water flow at sediment surface is reduced within the patches of biogenic structures. This improves the settlement of both inert and living particles (Friedrichs et al. 2000), and enhances the accumulation of passively transported meiofauna. Our study also highlights that OM, diatoms and EPS, which are important food sources for meiofauna (Higgins \& Thiel 1988, Giere 1993), are more abundant when tubes are present. Furthermore, biogenic structures are known to increase habitat complexity and protect meiofauna from predators (Bell 1985, Peachey \& Bell 1997). We, therefore, hypothesised that meiofauna would be more abundant in chambers with tubes compared to control chambers.

As expected, foraminifera were more abundant when the density of artificial tubes increased, as a probable result of a higher colonisation through passive transport and/or higher reproduction rates in sediments with higher OM content (Higgins \& Thiel 1988). However, the recolonisation and the development of the other meiofaunal groups were more rapid in bare sediments. Similarly, Eckman (1983) showed that, at the end of a one month intertidal experiment, meiofaunal abundances were highest in systems without tubes or at a medium tube density (corresponding to our LD treatment). Meiofauna are usually not limited by the abundance of trophic resources (Coull 1999) and other factors, such as physical context, could explain these meiofaunal patterns. Indeed, except for foraminifera, most meiofaunal organisms are able to relocate if one particular environment does not satisfy their optimal requirements (Palmer 1988, Armonies 1994, Olivier \& Retiere 2006). The increase in organic content at high tube density could have favoured hypoxic conditions (as suggested by the higher respiration rates) and, by cascade, may have hindered recruitment and devel- 
opment of meiofauna in the corresponding chambers (Higgins \& Thiel 1988, Gambi et al. 2009). Moreover, the increase of diatom abundance in the tube treatments was related, in our experiment, to a development of the biofilm matrix through EPS secretion. EPS can limit the consumption of diatoms by grazers, by linking cells together, thus making them difficult to ingest (Wotton 2004). The lower abundance of different meiofaunal groups, except foraminifera, in tube treatments could, therefore, be explained by deleterious physicochemical conditions and/or a weak access to trophic resources.

In our experiment, macrofaunal colonisation was mostly achieved by organisms which are known to be active swimmers (amphipods, errant annelids, etc.), but it still remained very low. However, the presence of biogenic structures strongly modified the final macrofaunal assemblages. Species of the genus Bathyporeia were typically found in the highly dynamic environments, which surrounded our experimental zone (Godet et al. 2010, Grant et al. 2012) and they were, therefore, restricted to the control treatments and excluded as soon as skimming flow occurred. Chambers with high tube density, where sediment stability and organic content both increased, were colonised by deposit-feeding worms such as Mediomastus fragilis and Scoloplos armiger, which may benefit from the increased deposition. Surprisingly, macrofaunal diversity and abundance were lower under skimming flow conditions, which contradicts other studies (Woodin 1978, Luckenbach 1986, Zuhlke 2001, Callaway 2006). However, our experimental design only followed the period of spring colonisation by adults, whereas previously cited studies integrate the influence of recruitment dynamics of larvae which may be higher under skimming flow conditions, in part due to lower resuspension rates (Desroy et al. 1997).

\section{Effects of biogenic structures on ecosystem functions}

Benthic diatoms are of crucial importance in the carbon budget of coastal areas (Admiraal 1984). The present work showed that diatom proliferation was stimulated when artificial biogenic structures were present and was associated with an increase of both gross primary production and respiration. As meiofaunal and macrofaunal densities were relatively low, benthic respiration was most likely due to bacterial assemblages, as demonstrated in other studies of intertidal areas (Schwinghamer et al. 1986, Azam et al.
1994, Hubas et al. 2007). However, we could not detect an increase of bacterial abundances during our experiment due to very high variability. An increase of bacterial activities under skimming flow conditions (van Duyl et al. 2000), for similar bacterial densities, might explain the relative increase of their respiration. The higher P/R ratio in the control treatment and the decline across treatments suggests a shift to heterotrophy when biogenic structures are present. This observation is consistent with the observed changes in meiofaunal and macrofaunal assemblages.

Sediment stability is an important feature of ecosystems subjected to high physico-chemical gradients, such as intertidal areas. The present work demonstrated that sediment particle adhesion, a proxy for sediment stability (Larson et al. 2009, Lubarsky et al. 2010), is increased when biogenic structures generate skimming flows. As sediment adhesion potential was strongly correlated to chl a and $C$, and colloidal carbohydrates and proteins concentrations, we hypothesize that diatoms were of particular importance for sediment stability through EPS secretion. EPS generally create a network which traps and binds particles together, increasing their functional size and decreasing seabed roughness, and ultimately increasing sediment adhesion and stability (Decho 1990, Paterson \& Hagerthey 2001, de Brouwer et al. 2002, Ludwig et al. 2005, Stal 2010). The potential influence of meiofauna and macrofauna communities on sediment stability is complex (Montserrat et al. 2008). By increasing sediment water content and microtopography, and by feeding on microorganisms which stabilise sediment, meiofauna and macrofauna promote sediment destabilisation (de Deckere et al. 2001). On the other hand, the mucus produced by some organisms consolidate sediments (Murray et al. 2002), and provides a food resource to microorganisms, maintaining their growth potential (Coull 1999), thereby stimulating EPS secretion (Hubas et al. 2010) and sediment stabilisation. In the present experiment, macrofauna was more abundant in the control treatment, where they could have promoted sediment erosion by bioturbation (de Deckere et al. 2001). However, because macrofaunal abundances were very low in the experimental chambers, we propose that the effect of the bioturbation on sediment stability was weak. The strong correlation between EPS content and sediment adhesive abilities suggested a high contribution of diatoms to any changes in sediment stability through their EPS secretion and confirmed that biostabilisation of sediment was poorly influenced by both meiofaunal and macrofaunal assemblages. 


\section{CONCLUSION}

The results of this in situ experiment involving artificial tubes mimics demonstrate that these biogenic structures, regardless of the organisms' activities, have a crucial influence in structuring benthic assemblages. By modifying hydrodynamics, they promote the development of microphytobenthic biofilms, in terms of photosynthetic biomass and EPS content. The alteration of microbial biomasses and activity, where these structures occur, affects the access of meiofaunal and macrofaunal organisms to trophic resources and modify the physical and chemical conditions in the sediment, therefore structuring these assemblages. The density and composition of microbial, meiofaunal and macrofaunal assemblages are, therefore, dependent on the presence and density of biogenic structures. These changes in benthic assemblages have an impact on the ecosystem functions by increasing the relative importance of heterotrophic processes and by improving sediment stability. We hypothesise that these effects will be common across different biogenic structures, with different shape and densities (Friedrichs et al. 2009), where they generate similar effects on hydro-sedimentary dynamics.

Acknowledgements. The authors thank I. Rauss, the Conservatoire du Littoral, the Sydicat Mixte des Espaces Littoraux de la Manche and the Syndicat Mixte Littoral Normand for their involvement in the project. We thank T. Abiven and the crew of 'Gwenn Ha Ruz' for their valuable help with fieldwork. A. Davis and 3 anonymous referees are acknowledged for constructive comments on the manuscript. This work received support from the 'ATM Biodiversite des microorganismes', from the École Normale Supérieure de Paris through its financial support to C.P., and D.M.P. received funding from MASTS (The Marine Alliance for Science and Technology for Scotland) and their support is gratefully acknowledged. MASTS is funded by the Scottish Funding Council (ref HR09011) and contributing institutions.

\section{LITERATURE CITED}

Admiraal W (1984) The ecology of estuarine sedimentinhabiting diatoms. In: Round FE, Chapman DJ (eds) Progress in ecological research, Vol 3. Biopress, Bristol, p 269-322

Armonies W (1994) Drifting meio- and macrobenthic invertebrates on tidal flats in Königshafen: a review. Helgol Meersunters 48:299-320

> Azam F, Smith DC, Steward GF, Hagström Å (1994) Bacteria-organic matter coupling and its significance for oceanic carbon cycling. Microb Ecol 28:167-179

> Barranguet C, Herman PMJ, Sinke JJ (1997) Microphytobenthos biomass and community composition studied by pigment biomarkers: importance and fate in the carbon cycle of a tidal flat. J Sea Res 38:59-70

Bell SS (1985) Habitat complexity of polychaete tube-caps: influence of architecture on dynamics of a meioepibenthic assemblage. J Mar Res 43:647-671

Black KS, Paterson DM (1996) LISP-UK: an holistic approach to the interdisciplinary study of tidal flat sedimentation Terr Nova 8:304-308

Boivin MEY, Greve GD, Garcia-Meza JV, Massieux B and others (2007) Algal-bacterial interactions in metal contaminated floodplain sediments. Environ Pollut 145: 884-894

> Burgess R (2001) An improved protocol for separating meiofauna from sediments using colloidal silica sols. Mar Ecol Prog Ser 214:161-165

Callaway R (2003) Long-term effects of imitation polychaete tubes on benthic fauna: they anchor Mytilus edulis (L.) banks. J Exp Mar Biol Ecol 283:115-132

Callaway R (2006) Tube worms promote community change. Mar Ecol Prog Ser 308:49-60

> Coull BC (1999) Role of meiofauna in estuarine soft-bottom habitats. Aust J Ecol 24:327-343

$>$ de Brouwer JFC, Ruddy GK, Jones TER, Stal LJ (2002) Sorption of EPS to sediment particles and the effect on the rheology of sediment slurries. Biogeochemistry 61: 57-71

de Brouwer JFC, Wolfstein K, Ruddy GK, Jones TER, Stal LJ (2005) Biogenic stabilization of intertidal sediments: The importance of extracellular polymeric substances produced by benthic diatoms. Microb Ecol 49:501-512

$>$ de Deckere E, Tolhurst TJ, de Brouwer JFC (2001) Destabilization of cohesive intertidal sediments by infauna. Estuar Coast Shelf Sci 53:665-669

Decho AW (1990) Microbial exopolymer secretions in ocean environments: their role(s) in food webs and marine processes. Oceanogr Mar Biol Annu Rev 28: 73-153

Desroy N, Olivier F, Retiere C (1997) Effects of individual behaviors, inter-individual interactions with adult Pectinaria koreni and Owenia fusiformis (Annelida, Polychaeta), and hydrodynamism on Pectinaria koreni recruitment. Bull Mar Sci 60:547-558

Eckman JE (1983) Hydrodynamic processes affecting benthic recruitment. Limnol Oceanogr 28:241-257

Eckman JE (1985) Flow disruption by an animal-tube mimic affects sediment bacterial colonization. J Mar Res 43: 419-435

Eckman JE, Nowell ARM, Jumars PA (1981) Sediment destabilization by animal tubes. J Mar Res 39:361-374

> Forster S, Graf G (1995) Impact of irrigation on oxygen flux into the sediment: intermittent pomping by Callianasse subterranea and 'piston-pumping' by Lanice conchilega. Mar Biol 123:335-346

> Friedrichs M, Graf G (2009) Characteristic flow patterns generated by macrozoobenthic structures. J Mar Syst 75 : 348-359

> Friedrichs M, Graf G, Springer B (2000) Skimming flow induced over a simulated polychaete tube lawn at low population densities. Mar Ecol Prog Ser 192:219-228

> Friedrichs M, Leipe T, Peine F, Graf G (2009) Impact of macrozoobenthic structures on near-bed sediment fluxes. J Mar Syst 75:336-347

B, Palmgren R, Keiding K, Nielsen PH (1996) Extraction of extracellular polymers from activated sludge using a cation exchange resin. Water Res 30:1749-1758

Gambi C, Bianchelli S, Perez M, Invers O, Ruiz JM, Danovaro R (2009) Biodiversity response to experimental induced hypoxic-anoxic conditions in seagrass sediments. Biodivers Conserv 18:33-54 
Giere O (1993) Meiobenthology. Springer Verlag, Berlin

Godet L, Le Mao P, Grant C, Olivier F (2010) Marine invertebrate fauna of the Chausey archipelago: an annotated checklist of historical data from 1828 to 2008. Cah Biol Mar 51:147-165

Grant C, Archambault P, Olivier F, McKindsey C (2012) Influence of 'bouchot' mussel culture on the benthic environment in a dynamic intertidal system. Aquacult Environ Interact 2:117-131

Higgins RP, Thiel H (1988) Introduction to the study of meiofauna, Smithsonian Institution Press, Washington, DC

> Hubas C, Lamy D, Artigas LF, Davoult D (2007) Seasonal variability of intertidal bacterial metabolism and growth efficiency in an exposed sandy beach during low tide. Mar Biol 151:41-52

> Hubas C, Sachidhanandam C, Rybarczyk H, Lubarsky HV, Rigaux A, Moens T, Paterson DM (2010) Bacterivorous nematodes stimulate microbial growth and exopolymer production in marine sediment microcosms. Mar Ecol Prog Ser 419:85-94

Jeffrey SW, Mantoura RFC, Wright SW (eds) (1997) Phytoplankton pigments in oceanography: guidelines to modern methods, UNESCO monographs on oceanographic methodology, Vol 10. UNESCO, Paris

> Jones CG, Lawton JH, Shachak M (1994) Organisms as ecosystem engineers. Oikos 69:373-386

> Larson F, Lubarsky HV, Gerbersdorf SU, Paterson DM (2009) Surface adhesion measurements in aquatic biofilms using magnetic particle induction: MagPI. Limnol Oceanogr Methods 7:490-497

- Lubarsky HV, Hubas C, Chocholek M, Larson F, Manz W, Paterson DM, Gerbersdorf SU (2010) The stabilisation potential of individual and mixed assemblages of natural bacteria and microalgae. PLoS ONE 5:e13794

$>$ Luckenbach MW (1986) Sediment stability around animal tubes: the roles of hydrodynamic processes and biotic activity. Limnol Oceanogr 31:779-787

> Ludwig R, Al-Horani FA, de Beer D, Jonkers HM (2005) Photosynthesis-controlled calcification in a hypersaline microbial mat. Limnol Oceanogr 50:1836-1843

- Migné A, Davoult D, Spilmont N, Menu D, Boucher G, Gattuso JP, Rybarczyk H (2002) A closed-chamber $\mathrm{CO}_{2}$-flux method for estimating intertidal primary production and respiration under emersed conditions. Mar Biol 140: 865-869

- Montserrat F, Van Colen C, Degraer S, Ysebaert T, Herman PMJ (2008) Benthic community-mediated sediment dynamics. Mar Ecol Prog Ser 372:43-59

Moulin FY, Guizien K, Thouzeau G, Chapalain G, Mülleners K, Bourg C (2007) Impact of an invasive species, Crepidula fornicata, on the hydrodynamics and transport properties of the benthic boundary layer. Aquat Living Resour 20:15-31

Murray JMH, Meadows A, Meadows PS (2002) Biogeomorphological implications of microscale interactions between sediment geotechnics and marine benthos: a review. Geomorphology 47:15-30

> Nowell ARM, Jumars PA (1984) Flow environments of aquatic benthos. Annu Rev Ecol Syst 15:303-328

> Olivier F, Retiere C (2006) How to leave or stay on the substratum when you can't swim? Evidence of the role of mucus thread secretion by postlarvae of Pectinaria koreni (Malmgren) in still water and flume experiments. Aquat Ecol 40:503-519

Palmer MA (1988) Dispersal of marine meiofauna: a review and conceptual model explaining passive transport and active emergence with implications for recruitment. Mar Ecol Prog Ser 48:81-91

Paterson DM, Hagerthey SE (2001) Microphytobenthos in contrasting coastal ecosystems: biology and dynamics. In: Reise K (ed) Ecological comparisons of sedimentary shores, Vol 151. Springer Verlag, Berlin p 105-125

- Paterson DM, Wiltshire KH, Miles A, Blackburn J and others (1998) Microbiological mediation of spectral reflectance from intertidal cohesive sediments. Limnol Oceanogr 43: 1207-1221

> Peachey RL, Bell SS (1997) The effects of mucous tubes on the distribution, behavior and recruitment of seagrass meiofauna. J Exp Mar Biol Ecol 209:279-291

> Schäfer H, Abbas B, Witte H, Muyzer G (2002) Genetic diversity of 'satellite' bacteria present in cultures of marine diatoms. FEMS Microbiol Ecol 42:25-35

Schwinghamer P, Hargrave B, Peer D, Hawkins CM (1986) Partitioning of production and respiration among size groups of organisms in a intertidal benthic community. Mar Ecol Prog Ser 31:131-142

Stal LJ (2010) Microphytobenthos as a biogeomorphological force in intertidal sediment stabilization. Ecol Eng 36: 236-245

Steward CC, Nold SC, Ringelberg DB, White DC, Lovell CR (1996) Microbial biomass and community structures in the burrows of bromophenol producing and non-producing marine worms and surrounding sediments. Mar Ecol Prog Ser 133:149-165

$>$ Taylor IS, Paterson DM (1998) Microspatial variation in carbohydrate concentrations with depth in the upper millimetres of intertidal cohesive sediments. Estuar Coast Shelf Sci 46:359-370

Thistle D, Reidenauer JA, Findlay RH, Waldo R (1984) An experimental investigation of enhanced harpacticoid (Copepoda) abundances around isolated seagrass shoots. Oecologia 63:295-299

> Toupoint N, Godet L, Fournier J, Retiere C, Olivier F (2008) Does Manila clam cultivation affect habitats of the engineer species Lanice conchilega (Pallas, 1766)? Mar Pollut Bull 56:1429-1438

van Duyl FC, de Winder B, Kop AJ, Wollenzien U (2000) Consequences of diatom mat erosion for carbohydrate concentrations and heterotrophic bacterial activities in intertidal sediments of the Ems-Dollard estuary. Cont Shelf Res 20:1335-1349

Volkenborn N, Robertson DM, Reise K (2009) Sediment destabilizing and stabilizing bio-engineers on tidal flats: cascading effects of experimental exclusion. Helgol Mar Res 63:27-35

- Woodin SA (1978) Refuges, disturbance, and community structure: a marine soft-bottom example. Ecology 59: 274-284

Woodin SA, Jackson JBC (1979) Interphyletic competition among marine benthos. Am Zool 19:1029-1043

Wotton RS (2004) The essential role of exopolymers (EPS) in aquatic systems. Oceanogr Mar Biol Annu Rev Vol 42: 57-94

Zuhlke R (2001) Polychaete tubes create ephemeral community patterns: Lanice conchilega (Pallas, 1766) associations studied over 6 years. J Sea Res 46:261-272

Zuhlke R, Blome D, van Bernem KH, Dittmann S (1998) Effects of the tube-building polychaete Lanice conchilega (Pallas) on benthic macrofauna and nematodes in an intertidal sandflat. Senckenb Marit 29:131-138 
Appendix 1. Meiofaunal and macrofaunal abundances

Table A1. Meiofaunal abundances (number of ind. per chamber; mean \pm SE) during the course of the experiment. Ctrl: control treatment, without tubes. LD: low tube density. HD: high tube density

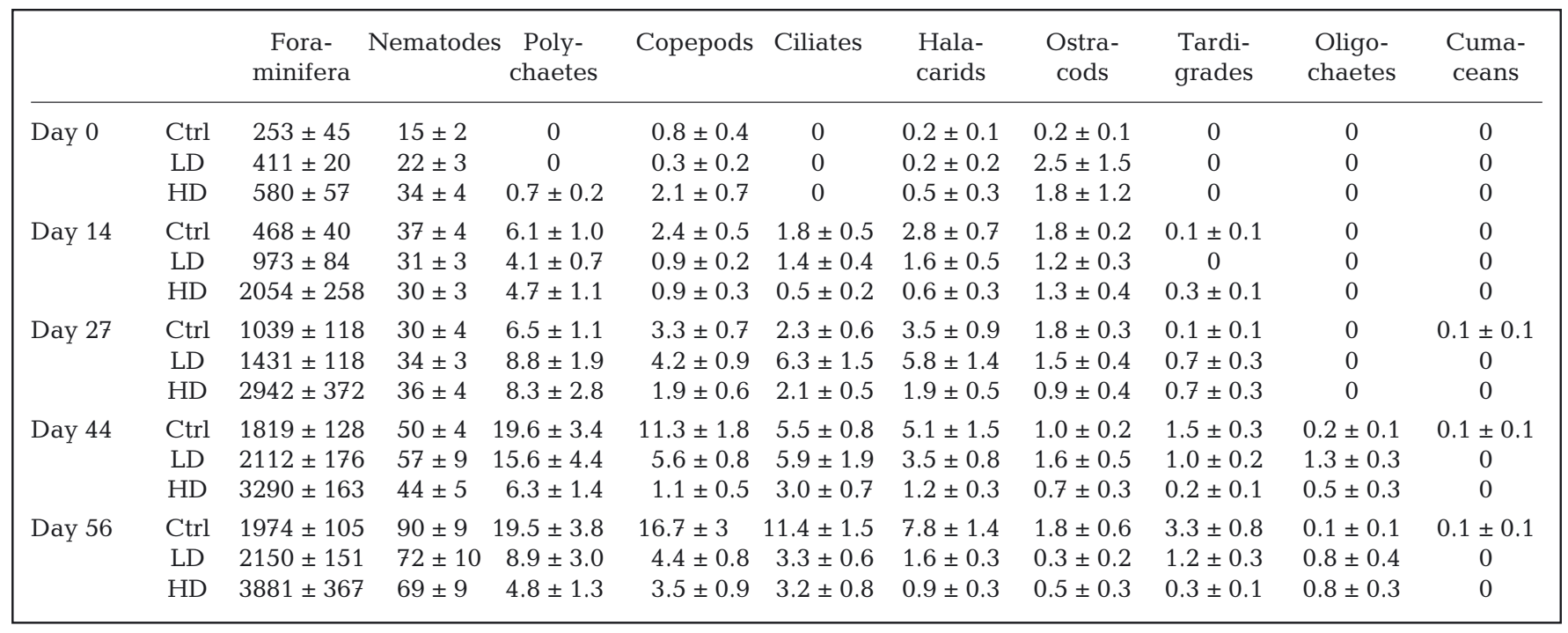

Table A2. Macrofaunal abundances (number of individuals per chamber) in the 12 benthic chambers at the end of the experiment. Ctrl: control treatment, without tubes. LD: low tube density. HD: high tube density

\begin{tabular}{|c|c|c|c|c|c|c|c|c|c|c|c|c|}
\hline & Ctrl 1 & Ctrl 2 & Ctrl 3 & Ctrl 4 & LD 1 & LD 2 & LD 3 & LD 4 & HD 1 & HD 2 & HD 3 & HD 4 \\
\hline Eteone longa & 0 & 0 & 0 & 1 & 0 & 0 & 0 & 0 & 0 & 0 & 0 & 0 \\
\hline Mediomastus fragilis & 0 & 0 & 0 & 0 & 0 & 0 & 4 & 4 & 2 & 1 & 0 & 0 \\
\hline Nephtys cirrosa & 1 & 1 & 1 & 0 & 1 & 1 & 1 & 1 & 2 & 1 & 4 & 1 \\
\hline Nephtys hombergii & 0 & 0 & 0 & 0 & 0 & 0 & 0 & 1 & 0 & 0 & 0 & 0 \\
\hline Notomastus latericeus & 0 & 0 & 0 & 0 & 0 & 1 & 0 & 0 & 0 & 0 & 0 & 0 \\
\hline Phyllodoce mucosa & 0 & 0 & 0 & 0 & 0 & 1 & 0 & 0 & 0 & 0 & 0 & 0 \\
\hline Pygospio elegans & 0 & 1 & 1 & 0 & 0 & 1 & 0 & 0 & 0 & 0 & 0 & 0 \\
\hline Scoloplos armiger & 0 & 0 & 0 & 0 & 0 & 1 & 1 & 1 & 0 & 0 & 0 & 0 \\
\hline Spio martinensis & 0 & 1 & 5 & 4 & 2 & 3 & 1 & 1 & 0 & 1 & 0 & 1 \\
\hline Loripes lucinalis & 0 & 0 & 0 & 0 & 0 & 0 & 0 & 1 & 0 & 0 & 0 & 0 \\
\hline Ruditapes philippinarum & 0 & 0 & 0 & 0 & 0 & 1 & 2 & 0 & 0 & 0 & 2 & 2 \\
\hline Nassarius reticulatus & 2 & 0 & 0 & 1 & 0 & 2 & 0 & 1 & 0 & 0 & 0 & 1 \\
\hline Cumopsis goodsir & 0 & 4 & 1 & 2 & 0 & 0 & 1 & 0 & 0 & 0 & 0 & 0 \\
\hline Bathyporeia guilliamsoniana & 5 & 7 & 9 & 4 & 0 & 0 & 0 & 0 & 0 & 0 & 0 & 0 \\
\hline Bathyporeia nana & 1 & 0 & 0 & 0 & 0 & 0 & 0 & 0 & 0 & 0 & 0 & 0 \\
\hline Bathyporeia sarsi & 2 & 1 & 4 & 6 & 2 & 5 & 0 & 0 & 0 & 0 & 0 & 0 \\
\hline Gammarus oceanicus & 0 & 0 & 0 & 1 & 8 & 0 & 7 & 0 & 0 & 1 & 0 & 0 \\
\hline Leptocheirus hirsutimanus & 0 & 1 & 0 & 0 & 0 & 0 & 0 & 0 & 0 & 0 & 0 & 0 \\
\hline Lysianassa insperata & 0 & 0 & 0 & 0 & 1 & 0 & 0 & 0 & 0 & 0 & 0 & 0 \\
\hline Urothoe brevicornis & 1 & 1 & 1 & 1 & 0 & 0 & 0 & 1 & 0 & 0 & 0 & 0 \\
\hline Carcinus or Liocarcinus sp. & 0 & 0 & 1 & 0 & 0 & 0 & 0 & 0 & 1 & 0 & 1 & 0 \\
\hline
\end{tabular}

Editorial responsibility: Matthias Seaman, Oldendorf/Luhe, Germany
Submitted: March 6, 2012; Accepted: July 3, 2012

Proofs received from author(s): September 21, 2012 